\title{
Patterns of knowledge and condom use among population groups: Results from the 2005 Ethiopian Behavioral Surveillance Surveys on HIV
}

\author{
Getnet Mitike $^{1}$, Damen Haile Mariam ${ }^{1}$, Amy Tsui $^{2}$
}

\begin{abstract}
Background: Behavioral surveys help interpret the magnitude of HIV/AIDS. We analyzed indicators of knowledge on HIV/AIDS and condom use among different groups of populations selected for behavioral surveillance in Ethiopia.

Methods: We used HIV/AIDS Behavioural Surveillance Surveys (BSS) data collected from ten target groups in Ethiopia. These were female sex workers, military personnel, police force, pastoralists, long distance truck drivers, intercity bus drivers, road construction workers, teachers, factory workers and ANC catchment populations.

Results: Data from 14,524 individuals were analyzed. The majority were male (63.6\%). Knowledge of the three preventive methods (abstinence, faithfulness and consistent condom use), misconceptions and comprehensive knowledge was $57 \%, 75 \%$ and $18.5 \%$, respectively. Female sex workers and the defence force showed positive results in using condom during last sexual encounter and did so consistently with non regular sexual partners and paying partners. Women, pastoralists and the illiterate were negatively impacted.

Conclusion: Inadequate and incorrect knowledge on HIV/AIDS was observed with special deficiency among the underserved groups such as pastoralists. Women and the older age group were found to be at a disadvantage. The findings indicate the need to expand prevention activities to hard-to-reach groups and such a certain specific population segments. Population groups such as female sex workers and the defense force that were known to be severely affected by the epidemic and are focus of HIV/AIDS interventions showed positive behaviors. Although this is encouraging, considerable proportion of the study groups did not use condom during sex with non regular partners. This underscores the importance of intensifying interventions across all groups and extended to their localities. [Ethiop J Health Dev. 2011;25(1):35-45]
\end{abstract}

\section{Background}

More than two decades have passed since the evident of HIV in Ethiopia $(1,2)$. In spite of the indications that HIV prevalence is leveling off at the incidence global level, Ethiopia has remained one of the countries with high number of people living with HIV/AIDS (3). The national estimate of the HIV adult prevalence was $2.1 \%$ with $7.7 \%$, and $0.9 \%$ urban and rural prevalence respectively (MOH report, 2007). This estimate was higher than the Ethiopian DHS and lower than the estimate by the ANC sero-surveillance $(4,5)$ which were $1.4 \%$ and $3.5 \%$ respectively. Lack of serial quality data on behavioral aspects of HIV/AIDS had made the interpretation of the magnitude of HIV/AIDS difficult (6). Among the groups that were identified for surveillance, female sex workers, truck drivers, uniformed services and mobile groups were the earliest ones (7-9). Subsequently, the youth, teachers, road construction workers, pastoralist communities along transport corridors and other mobile groups such as intercity bus drivers were identified as risk groups for behavioral surveillance surveys. The road construction workers were focused on because of the expanding road construction activities along the highways joining provincial towns to Addis Ababa. Biological surveillance of HIV was established since the beginning of the epidemic as in many of the sub-Saharan countries. The surveillance was done on women attending antenatal care (ANC) services at health facilities in the country. In subsequent activities, the ANC catchment population was included as one of the target groups for behavioral surveys.

Conventional household surveys usually fall short of penetrating high-risk groups, which is important in driving the HIV epidemic. The BSS employs sampling methods that better capture hard-to-reach populations through the use of standardized methodologies and tools that help comparison and monitoring of risk behaviors overtime (10). Ethiopia has already conducted two rounds of behavioral surveys three years apart. Both rounds of surveys revealed a high level of awareness of HIV/AIDS (11, 12). However, the level of comprehensive knowledge that measured, with six questions related to "knowledge of the three preventive methods" and "absence of misconceptions" was very low. One of the main reasons for the low comprehensive knowledge was the prevailing misconceptions and erroneous messages $(11,12)$ although such is knowledge considered to be one of the most important precursors for behavior change.

The most important assumption in behavioral interventions is people who are informed and equipped with the necessary skills to make better decisions in protecting themselves against HIV infection. Changes in the behavior of people measured by behavioral surveys may be attributed to several interventions focused on

\footnotetext{
${ }^{1}$ Addis Ababa University, School of Public Health, P.O. Box 9713, Email: getnetmk@gmail.com, Addis Ababa, Ethiopia;

${ }^{2}$ Johns Hopkins University, School of Public Health, Department of Population and Family Health Sciences, USA
} 
redacting of high-risk behaviors. Along with other data sources, information produced by behavioral surveillance surveys would help guide and interpret intervention programs by providing trends in risk behaviors among various segments of the population (10).

Using the BSS data, the objective of this analysis is to measure the pattern of essential knowledge about HIV/AIDS and condom use among female sex workers, teachers, population of antenatal care catchment areas, long distance truck drivers, intercity bus drivers, pastoralists, road construction workers, police and, defence forces and factory workers to inform program people to intensify calibrated interventions amongst these groups. It will also help as background information for subsequent analyses of data on different aspects of HIV/AIDS behavioral surveillance.

\section{Methods}

This study used behavioural data on HIV/AIDS/STIs collected in 2005 in Ethiopia. Obtained from the cross sectional HIV/AIDS/STIs behavioural surveillance surveys (BSS) on 10 target population groups.

Target populations and sites: The selection of target groups was based on the distribution of HIV in the different groups relevance of the groups in spreading and maintaining HIV/AIDS, sexual network related to location, mobility or focus of interventions. Table 1 shows the target populations, number of sites, size of sample and sampling methods.

Table 1: Distribution, sample size and sampling method for study population, Ethiopia 2005

\begin{tabular}{|c|c|c|c|}
\hline Target population & $\begin{array}{l}\text { Data ( Sample } \\
\text { interviewed) }\end{array}$ & Sampling method & $\begin{array}{l}\text { Number of sites and } \\
\text { primary sampling unit }\end{array}$ \\
\hline Truckers & 600 & Time-location clusters & 5 truck weighting sites \\
\hline Inter city bus driver & 600 & Time-location clusters & 1 central site \\
\hline Female sex worker & 1398 & Time-location clusters* & 3 urban centers \\
\hline Pastoralists & 1608 & $\begin{array}{l}\text { Two - stage sampling } \\
\text { Respondents selected using } \\
\text { systematic random sampling }\end{array}$ & 2 regions- villages \\
\hline Factory workers & 416 & Systematic random sampling & 1 factory \\
\hline Military & 1305 & $\begin{array}{l}\text { Two - stage sampling } \\
\text { Respondents selected using } \\
\text { systematic random sampling }\end{array}$ & 2 sties - brigade \\
\hline $\begin{array}{l}\text { Population in ANC } \\
\text { catchment areas }\end{array}$ & 5207 & $\begin{array}{l}\text { Two - stage sampling } \\
\text { Respondents selected using } \\
\text { systematic random sampling }\end{array}$ & $\begin{array}{l}8 \text { sites - enumeration } \\
\text { area }\end{array}$ \\
\hline Road CW & 1623 & $\begin{array}{l}\text { Two - stage sampling } \\
\text { Respondents selected using } \\
\text { systematic random sampling }\end{array}$ & $\begin{array}{l}7 \text { sites, } 4 \text { directions - } \\
\text { construction sites }\end{array}$ \\
\hline Police force & 1071 & $\begin{array}{l}\text { Two - stage sampling } \\
\text { Respondents selected using } \\
\text { systematic random sampling }\end{array}$ & 7 sites - police stations \\
\hline Teachers & 696 & $\begin{array}{l}\text { Two - stage sampling } \\
\text { Respondents selected using } \\
\text { systematic random sampling }\end{array}$ & 11 regions - schools \\
\hline Total & 14524 & & \\
\hline
\end{tabular}

Sample size: For sample size estimation, the formula for two proportions was used for each target group. In calculating the sample size for each target group, assumptions and findings of the first round BSS were used. Sample size determination and sampling procedures followed guidelines for BSS (10). Design effect and power were considered in estimating the sample size for each corresponding target group.

\section{Instruments and data collection procedures:}

The BSS used standardized questionnaires that were pretested and adapted to the Ethiopian situation. Almost all the questions were the same for all targets except a few that were specific to each target group. The questionnaires were translated into Amharic, Oromifa, and Afarigna and translated back for checking consistency with the English version; they were field tested before use.
The data collectors had completed high school and most were from the Central Statistical Agency (CSA). In order to ensure confidence and convenience, the interviewers were sex matched with interviewees and were selected from different areas of the same region and speaking the same language as the interviewees. This arrangement was preferred to avoid possibilities of acquaintance between the interviewer and interviewee.

\section{Data Quality}

The BSS used highly supervised data collection and data handling procedures that followed manuals of the CSA. One person supervised a maximum of four to six data collectors and each questionnaire was checked for completeness and consistency on the spot. All data collected were handled and processed by CSA. 


\section{Variables}

a) Explanatory variables: age, sex, education and target group $b)$ the outcome variables included: knowledge of prevention methods, misconception, comprehensive knowledge, consistent condom use with non regular sexual partner and paying sexual partner; condom use during last sexual encounter with non regular sexual partner and paying sexual partner.

\section{Data analysis}

Data were analyzed using SPSS version 13 and Stat version 9 statistical soft wares. We used bivariate analysis and then logistic regression controlling for age, sex and education levels. Adjusted Odds Ratio and 95\% Confidence Interval were calculated to indicate statistical associations at 5\% significance level.

The study was approved by the Research and Publication Committee of the Faculty of Medicine and the BSS by the Ethiopian Science and Technology Agency.

\section{Operational definitions}

Knowledge of prevention methods: knowledge of prevention included three questions measuring (abstinence, being faithful and condom use):

Can people protect themselves from HIV, the virus that causes AIDS by using condom correctly every time they have sex?

Can people protect themselves from HIV by having one uninfected faithful sexual partner? (Excluding other transmission routes)

Can people protect themselves from HIV by abstaining from sexual intercourse? (excluding other transmission routes).

A person was classified as knowledgeable about prevention if $\mathrm{s} /$ he mentioned all three methods.

Misconceptions to three: knowledge on misconceptions was measured if a person had rejected three common misconceptions. These misconceptions were common in the country.

Can a person get the HIV virus from eating uncooked eggs from a chicken that swallowed a condom?

Can a person get the HIV virus from eating raw meat prepared by a person infected with HIV?

Do you think that a healthy-looking person can be infected with HIV, the virus that causes AIDS?

Comprehensive knowledge: this index was built based on the answers to six questions: three questions on knowledge of prevention and three questions on common misconceptions. A person was considered as having comprehensive knowledge if $\mathrm{s} /$ he knew all the three preventive methods and rejected the three misconceptions.
Populations in the ANC catchment area: This refers to the general (both rural and urban) population surveillance is taking place in the country. It included living in ANC surveillance sites.

Paying sexual partner: Having sex with sexual partner in exchange for money.

Non regular sexual partner: non commercial sexual partnership unmarried or cohabiting partners.

\section{Results}

Table 2 shows the characteristics of the study sample (14,524 individuals in the ten target groups). Amongst them, 35.8\% came from population in ANC catchment areas and $11.17 \%$ were road construction workers, $11.2 \%$ were pastoralists, $9.6 \%$ were female sex workers, $9 \%$ were police, and $7.4 \%$ were members of the defence force. The remaining accounted for less than 5\% each. The majority were male (63.6\%). Some groups did not have females in the sample (long distance drivers and, to some extent, the uniformed services and road construction workers).

As indicated in Table 3, knowledge of the three preventive methods was $57 \%$, white the level of misconception concerning the three prevailing common ones was very high $(75 \%)$. The proportion of people with comprehensive knowledge was $18.5 \%$ (8.9\% in females and $24 \%$ in males).

Table 4 indicates distribution of major outcomes by sex and target groups. The outcomes included knowledge of prevention methods, level of misconceptions, level of comprehensive knowledge, consistent condom use and condom use during last sexual encounter with a non regular sexual partner and with paying sexual partners. Knowledge of the preventive methods ranged between $39.3 \%$ in pastoralists to $80.0 \%$ in members of defense forces in males. In females, the lowest was for pastoralists $(18.5 \%)$ and the highest for female members of the police force $(77.8 \%)$. Knowledge of preventive methods was consistently low in males and females of the pastoralist communities. Knowledge of preventive methods was $43.3 \%$ and $64.8 \%$ amongst females and males, respectively.

The proportions of people with the highest and lowest misconceptions about three questions were $96.1 \%$ and $35.3 \%$ in female pastoralists and female members of the defense forces respectively (number of females in the defense forces was very low). Female teachers had a lower level of misconceptions compared to the other groups excluding female members of the defense forces where the number was too small. In general misconceptions were high both in females and males, $85.6 \%$ and $68.7 \%$. 
Comprehensive knowledge was generally low (18.5\%), $8.4 \%$ and $24 \%$ for females and males respectively. The level of comprehensive knowledge was lowest amongst women pastoralists $2.1 \%$ compared to that among female members of the defense forces which was the highest $(52.9 \%)$.

Consistent condom use with non-regular sexual partners was $60.8 \%$ for females and $68 \%$ for males. Consistent condom use with non regular sexual partners was lowest for pastoralist (none out of five); the highest was for female sex workers $(70 \%)$. In males the highest was for intercity bus drivers $(83.7 \%)$ and the lowest was among pastoralists $(21.4 \%)$.

Condom use during last sexual encounter with a nonregular sexual partner was $66 \%$ for females and $76.6 \%$ for males. Consistent condom use was the lowest among female pastoralists (none reported use but numbers were small) and the highest was amongst female sex workers (93.8\%). Amongst males, consistent condom use was highest (90.4\%) in members of the defense forces.

In general, consistent condom use with paying sexual partners was high $(93.0 \%$ for females and $86.2 \%$ for males). This was skewed towards females because of the female sex workers. Consistent condom use was lowest amongst female factory workers $(62.5 \%)$.

Condom use during last intercourse with paying partner was $97.5 \%$ for females and $96 \%$ for males. Condom use during last sexual encounter was lowest for female pastoralists and factory workers (numbers were too small) while the highest was for female sex workers. In males, condom use during last sexual encounter was highest in members of the defense force $(98.3 \%)$ and lowest for factory workers $(62.5 \%)$.

Table 5 indicates socio-demographic variables by composite indicators of knowledge with adjusted odds ratios. Female sex workers $(\mathrm{OR}=7.6995 \% \mathrm{CI}=6.57$, 9.01), members of the defence forces $(\mathrm{OR}=2.5795 \%$ $\mathrm{CI}=2.19,3.02)$, factory workers $(\mathrm{OR}=2.3695 \% \mathrm{CI}=1.84$, $3.02)$, intercity bus drivers $(\mathrm{OR}=2.1795 \% \mathrm{CI} 1.76,2.69)$, long distance truck drivers $(\mathrm{OR}=2.0795 \% \mathrm{CI}=1.68$, $2.55)$, road construction workers $(\mathrm{OR}=1.4295 \% \mathrm{CI} 1.23$, 1.64) and members of the police force $(\mathrm{OR}=1.4095 \%$ $\mathrm{CI}=1.19,1.64)$ were more likely to mention the three preventive methods than population in ANC catchment areas.

Correct identification of the three questions on misconceptions was statistically significantly higher for teachers $(\mathrm{OR}=1.93,95 \% \mathrm{CI}=1.61,2.31)$, female sex workers $(\mathrm{OR}=1.52,95 \%$ CI $1.26,1.83)$, members of the police force $(\mathrm{OR}=1.3995 \%$ CI 1.19, 1.62), members of the defence forces $(\mathrm{OR}=1.2295 \% \mathrm{CI}=1.05,1.41)$, and factory workers $(\mathrm{OR}=1.6395 \% \mathrm{CI}=1.29,2.05)$.

Teachers $(\mathrm{OR}=1.6495 \% \mathrm{CI}=1.6,1.99)$, long distance truck drivers $(\mathrm{OR}=1.45 \quad 95 \% \quad \mathrm{CI}=1.18,1.79)$, road construction workers, female sex workers $(\mathrm{OR}=2.1195 \%$ $\mathrm{CI}=1.10,2.61)$, members of the police force $(\mathrm{OR}=1.48$ $95 \% \mathrm{CI}=1.25,1.75)$, members of the defense forces $(\mathrm{OR}=1.28 \quad 95 \% \quad \mathrm{CI}=1.08, \quad 1.50)$, factory workers $(\mathrm{OR}=2.2795 \% \mathrm{CI}=1.78,2.88)$ and road construction workers $(\mathrm{OR}=1.1795 \% \mathrm{CI}=1.00,1.37)$ were more likely to have comprehensive knowledge compared to the population in ANC catchment area. Female sex workers and factory workers were twice as likely to have comprehensive knowledge when compound will population in ANC catchment area.

Among the socio-demographic factors, the illiterate and those with primary education were less likely to have knowledge of preventive methods ( $\mathrm{OR}=0.24 \quad 95 \%$ $\mathrm{CI}=0.22,0.27 ; \mathrm{OR}=0.6695 \% \mathrm{CI}=0.60,0.72)$, reject the common misconceptions $(\mathrm{OR}=0.2095 \% \mathrm{CI}=0.17,0.23$; $\mathrm{OR}=0.4695 \% \quad \mathrm{CI}=0.42,0.51)$, and have practical comprehensive knowledge $(\mathrm{OR}=0.17 \quad 95 \% \mathrm{CI}=0.14$, 0.20 ; $\mathrm{OR}=0.4795 \% \mathrm{CI}=0.42,0.52)$ compared to those with high school and above education. Males were more likely to have better knowledge on preventive methods $(\mathrm{OR}=1.9995 \% \mathrm{CI}=1.81,2.20)$, reject the common misconceptions $(\mathrm{OR}=1.9895 \% \mathrm{CI}=1.75,2.24)$, and have a comprehensive knowledge $(\mathrm{OR}=2.37 \quad 95 \% \mathrm{CI}=2.04$, 2.74).

People in the age group 35 years and above were less likely to have knowledge of preventive methods $(\mathrm{OR}=0.74 \quad 95 \% \quad \mathrm{CI}=0.67, \quad 0.82)$, reject common misconceptions $(\mathrm{OR}=0.7795 \% \mathrm{CI}=0.69,0.87)$, and have comprehensive knowledge ( $\mathrm{OR}=0.70 \quad 95 \% \quad \mathrm{CI}=0.62$, $0.80)$ than age group $15-24$ years.

Table 6 shows condom use with non-regular and paying sexual partners amongst the different target groups. In our analysis, age, sex and education were controlled while the population in ANC catchment areas was used as the referent group. Consistent condom use with non regular sex partners was significantly higher for intercity bus drivers $(\mathrm{OR}=4.15 \quad 95 \% \quad \mathrm{CI}=1.98, \quad 8.69)$, $\mathrm{road}$ construction workers $(\mathrm{OR}=2.1195 \% \mathrm{CI}=1.16,3.85)$, female sex workers $(\mathrm{OR}=3.1195 \% \mathrm{CI}=1.19,8.14)$ and members of the defense forces $(\mathrm{OR}=2.1495 \% \mathrm{CI}=1.12$, 4.10) than ANC catchment population. Intercity bus drivers $(\mathrm{OR}=4.0695 \% \mathrm{CI}=1.73,9.53)$ and female sex workers $(\mathrm{OR}=5.2195 \% \mathrm{CI}=1.89,14.33)$ were more likely to report condom use during last sexual encounter with non-regular partners than population in the ANC catchment areas. For members of the defense forces, it was marginally significant $(\mathrm{p}=0.06)$.

Female sex workers were more likely to report consistent condom use with paying partners $(\mathrm{OR}=4.56 \quad 95 \%$ $\mathrm{CI}+1.40,14.84)$ than ANC catchments populations. Consistent condom use was not statistically significantly different for the rest of the study groups. On the other hand, long distance truck drivers ( $\mathrm{OR}=5.96 \quad 95 \%$ $\mathrm{CI}=1.05,33.80)$, female sex workers $(\mathrm{OR}=5.9895 \%$ 
$\mathrm{CI}=1.15,31.05)$ and members of the defense force $(\mathrm{OR}=11.9195 \%$ CI $3.56,39.85)$ were more likely to report condom use during last sexual encounter with paying partners compared to population in ANC catchment areas. Female sex workers were five times as likely to report consistent condom use with paying sexual partner as the population in ANC catchment areas.

Table 2: Characteristics of the study populations, BSS Ethiopia, $2005(\mathrm{~N}=14,524)$

\begin{tabular}{lll}
\hline Target groups & Number & Percent \\
\hline Teachers & 696 & 4.79 \\
Population of antenatal care catchments areas & 5,207 & 35.85 \\
Long distance truck drivers & 600 & 4.13 \\
Intercity bus drivers & 600 & 4.13 \\
Pastoralists & 1,608 & 11.07 \\
Road construction workers & 1,623 & 11.17 \\
Females sex workers & 1,398 & 9.63 \\
Police force & 1,071 & 7.37 \\
Defense forces & 1,305 & 8.99 \\
Factory workers & 416 & 2.86 \\
Age of Respondents & & \\
15-24 & 5,383 & 38.03 \\
25-34 & 5,272 & 37.25 \\
35-59 & 3,498 & 24.72 \\
Education & & \\
Illiterates & 4,257 & 30.28 \\
Primary education & 4,521 & 32.16 \\
Secondary and above & 5,279 & 37.55 \\
Sex of respondents & & \\
Female & 5,276 & 36.33 \\
Male & 9,246 & 63.67 \\
\hline
\end{tabular}

Table 3: Behavioral indicators for the study populations, BSS Ethiopia, $2005(\mathbf{N}=14,524)$

\begin{tabular}{lll}
\hline Programmatically important preventive methods (a) & & \\
\hline Knows none & 1,469 & 10.11 \\
Knows one & 1,312 & 9.03 \\
Knows two & 3.440 & 23.68 \\
$\quad$ Knows three & 8,303 & 57.17 \\
Misconceptions about the common three (b) & & 75.22 \\
$\quad$ Have at least one misconception & 10,925 & 24.78 \\
$\quad$ No misconception & 3,599 & \\
Misconceptions about the six questions & & 20.74 \\
$\quad$ No misconception & 3.013 & 20.13 \\
$\quad$ Have one misconception & 2,924 & 59.12 \\
$\quad$ Have more than one misconception & 8,587 & \\
Comprehensive knowledge (a+b) & & 81.5 \\
$\quad$ No comprehensive knowledge & 11,837 & 18.5 \\
$\quad$ Has comprehensive knowledge & 2,687 & 3.19 \\
Condom use last sex with paid/paying partner (n=2,103) & & 96.81 \\
$\quad$ Did not us during condom & 67 & \\
$\quad$ Used condom & 2,036 & 9.99 \\
Consistent condom use with paid partner (n=2103) & & 90.01 \\
$\quad$ Did not use condom & 210 & 24.25 \\
$\quad$ Used condom & 1,893 & 75.75 \\
Condom use with non-regular partner (n=668) & & 33.08 \\
$\quad$ Did not use condom & 162 & 66.92 \\
$\quad$ Used condom & 506 & \\
$\quad$ Did not use condom & & \\
$\quad$ Used condom & 221 & 447 \\
\hline
\end{tabular}




\begin{tabular}{|c|c|c|c|c|c|c|c|c|}
\hline \multirow[t]{2}{*}{ Characters } & & \multicolumn{3}{|c|}{ Knowledge indicators n (\%) } & \multirow{2}{*}{\multicolumn{2}{|c|}{$\begin{array}{ll}\begin{array}{l}\text { Condom use with paid } \\
\text { partner } \mathrm{n}(\%)\end{array} & \\
\text { Consistent }^{*} & \text { Last set }^{*}\end{array}$}} & \multirow{2}{*}{$\begin{array}{l}\text { Condom use } \\
\text { partner n (\%) } \\
\text { Consistent }^{\star}\end{array}$} & \multirow{2}{*}{$\begin{array}{l}\text { with paid } \\
\text { Last set }^{*}\end{array}$} \\
\hline & & $\begin{array}{l}\text { Knowledge of } \\
\text { Prevention }\end{array}$ & Misconception 3 & $\begin{array}{l}\text { Comprehensive } \\
\text { knowledge }\end{array}$ & & & & \\
\hline Teachers gender $(n=696)$ & & Yes & Yes & Yes & Yes & Yes & Yes & Yes \\
\hline Female & $104(14.9)$ & $59(56.7)$ & $60(57.7)$ & $28(42.3)$ & $3(60.0)$ & $3(50.0)$ & 0 & 0 \\
\hline Male & $592(85.1)$ & $384(65.0)$ & $270(45.6)$ & $233(39.4)$ & $31(73.8)$ & $37(88.1)$ & $18(85.7)$ & $19(90.5)$ \\
\hline \multicolumn{9}{|l|}{ ANC Population ( $n=5207)$} \\
\hline Female & $2621(50.3)$ & $802(30.6)$ & $2323(88.6)$ & $156(6.0)$ & $12(57.2)$ & $12(57.2)$ & $12(80.0)$ & $14(93.3)$ \\
\hline Male & $2586(49.7)$ & $1425(55.1)$ & $1917(74.1)$ & $496(19.2)$ & $42(56.3)$ & $51(67.1)$ & $22(78.6)$ & $23(82.1)$ \\
\hline \multicolumn{9}{|c|}{ Long distance truck drivers $(n=600)$} \\
\hline Male & 600 & $457(76.2)$ & $394(65.7)$ & $174(29.0)$ & $31(70.5)$ & $33(75.0)$ & $50(80.6)$ & $60(96.8)$ \\
\hline \multicolumn{9}{|l|}{ Intercity bus drivers $(n=600)$} \\
\hline Male & 600 & $469(78.2)$ & $424(70.7)$ & $139(23,2)$ & $72(83.7)$ & $77(89.5)$ & $54(91.5)$ & $59(100)$ \\
\hline \multicolumn{9}{|l|}{ Pastoralists $(n=1608)$} \\
\hline Female & $794(49.4)$ & $147(18.5)$ & $763(96.1)$ & $17(2.1)$ & 0 & 0 & 0 & 0 \\
\hline Male & $814(50.6)$ & $320(39.3)$ & $722(88.7)$ & $59(7.2)$ & $3(21.4)$ & $5(35.7)$ & 0 & 0 \\
\hline \multicolumn{9}{|c|}{ Road construction workers $(n=1623)$} \\
\hline Female & $24(1.5)$ & $17(70.8)$ & $14(58.3)$ & $56(25.0)$ & 0 & 0 & 0 & 0 \\
\hline Male & $1599(98.5)$ & $1084(67.8)$ & $1097(68.6)$ & $383(24.0)$ & $100(69.0)$ & $112(77.2)$ & $84(74.3)$ & $103(91.2)$ \\
\hline \multicolumn{9}{|c|}{ Female sex workers $(n=1395)$} \\
\hline Female & 1396 & $1060(75.9)$ & $1171(83.9)$ & $179(12.8)$ & $42(70.0)$ & $47(78.3)$ & $1088(93.8)$ & $103(91.2)$ \\
\hline \multicolumn{9}{|l|}{ Police force $(n=1071)$} \\
\hline Female & $162(15.1)$ & $126(77.8)$ & $108(66.7)$ & $45(27.8)$ & 0 & 0 & 0 & 0 \\
\hline Male & $909(84.9)$ & $613(67.4)$ & $530(58.3)$ & $295(32.5)$ & $34(63.0)$ & $42(77.8)$ & $24(77.4)$ & $31(100)$ \\
\hline \multicolumn{9}{|l|}{ Defense forces $(n=1305)$} \\
\hline Female & $17(1.3)$ & $11(64.7)$ & $6(35.3)$ & $9(52.9)$ & 0 & 0 & 0 & 0 \\
\hline Male & $1288(98.7)$ & $1030(80.0)$ & $860(66.8)$ & $331(25.7)$ & $70(71.4)$ & $78(79.6)$ & $536(90.4)$ & $583(98.3)$ \\
\hline \multicolumn{9}{|l|}{ Factory workers $(n=416)$} \\
\hline Female & $158(38.0)$ & $90(57.0)$ & $122(77.2)$ & $28(17.7)$ & $2(50.0)$ & $2(40.0)$ & 0 & 0 \\
\hline Male & $258(62.0)$ & $208(80.6)$ & $142(55.0)$ & $109(42.2)$ & $5(41.7)$ & $7(58.3)$ & $5(62.5)$ & $5(62.5)$ \\
\hline \multicolumn{9}{|l|}{ Total $(n=14522)$} \\
\hline Female & $5276(36.3)$ & $2312(43.8)$ & $4567(85.6)$ & $468(8.9)$ & $59(60.8)$ & $64(66.0)$ & $1100(93.0)$ & $1153(97.5$ \\
\hline Male & $9246(63.7)$ & $5991(64.8)$ & $5356(68.7)$ & $2219(24.0)$ & $388(68.0)$ & $422(76.6)$ & $793(86.2)$ & $883(96.0)$ \\
\hline
\end{tabular}

consistent condom use with non regular partner and condom use during last sex with paid partner for paid sex; 


\begin{tabular}{|c|c|c|c|}
\hline Socio-demographic variables & $\begin{array}{l}\text { Has knowledge of prevention } \\
\text { AOR }(95 \% \mathrm{Cl})\end{array}$ & $\begin{array}{l}\text { Rejected } 3 \text { common misconceptions } \\
\text { AOR }(95 \% \mathrm{Cl})\end{array}$ & $\begin{array}{l}\text { Has comprehensive knowledge } \\
\text { AOR }(95 \% \mathrm{Cl})\end{array}$ \\
\hline \multicolumn{4}{|l|}{ Target group } \\
\hline Teachers & $0.96(0.80-1.16)$ & $1.93(1.61-2.31)$ & $1.64(1.36-1.99)$ \\
\hline Long distance truck drivers & $2.07(1.68-2.55)$ & $1.19(0.98-1.46)$ & $1.45(1.18-1.79)$ \\
\hline Intercity bus drivers & $2.17(1.76-2.69)$ & $0.88(0.72-1.08)$ & $0.99(0.79-1.23)$ \\
\hline Pastoralists & $1.06(0.92-1.22)$ & $0.81(0.65-1.00)$ & $0.86(0.65-1.12)$ \\
\hline Road construction workers & $1.42(1.23-1.64)$ & $1.13(0.98-1.31)$ & $1.17(1.00-1.37)$ \\
\hline Female sex workers & $7.69(6.57-9.01)$ & $1.52(1.26-1.83)$ & $2.11(1.70-2.61)$ \\
\hline Defense forces & $2.57(2.19-3.02)$ & $1.22(1.05-1.41)$ & $1.28(1.08-1.50)$ \\
\hline Factory workers & $2.36(1.84(3.02)$ & $1.63(1.29-2.05)$ & $2.27(1.78-2.88)$ \\
\hline ANC catchment area population & 1.00 & 1.00 & 1.00 \\
\hline \multicolumn{4}{|l|}{ Education } \\
\hline Illiterate & $0.24(0.22-0.27)$ & $0.20(0.17-0.23)$ & $0.17(0.14-0.20)$ \\
\hline Primary education & $0.66(0.66-0.72)$ & $0.46(0.42-0.51)$ & $0.47(0.42-0.52)$ \\
\hline High school and higher & 1.00 & 1.00 & 1.00 \\
\hline \multicolumn{4}{|l|}{ Age group } \\
\hline $15-24$ & 1.00 & 1.00 & 1.00 \\
\hline $35-59$ & $0.74(0.67-0.82)$ & $0.77(0.69-0.87)$ & $0.70(0.62-0.80)$ \\
\hline \multicolumn{4}{|l|}{ Sex } \\
\hline Female & 1.00 & 1.00 & 1.00 \\
\hline Male & $1.99(1.81-2.20)$ & $1.98(1.75-2.24)$ & $2.37(2.04-2.74)$ \\
\hline
\end{tabular}

AOR=adjusted odds ratio

Table 6: Consistent condom use and condom use at list sex with non regular partner 12 months and paid sex partner by target groups, Ethiopia, 2005 Non regular partner $(n=668)$ Paid partner $(\mathbf{n}=2103)$

\begin{tabular}{|c|c|c|c|c|c|c|c|c|}
\hline \multirow[b]{3}{*}{ Target group } & \multicolumn{4}{|c|}{ Non regular partner $(n=668)$} & \multicolumn{4}{|c|}{ Paid partner $(n=2103)$} \\
\hline & \multicolumn{2}{|c|}{ Consistent condom use } & \multicolumn{2}{|c|}{ Condom use doring last } & \multicolumn{2}{|c|}{ Consistent condom use } & \multicolumn{2}{|c|}{ Condom use during last sex } \\
\hline & AOR (95\%) & $\mathbf{P}$ & AOR (95\%) & $\mathbf{P}$ & AOR (95\%) & $\mathbf{P}$ & AOR (95\%) & $\mathbf{P}$ \\
\hline Teachers & $1.61(0.74-3.51)$ & 0.23 & $2.08(0.81-5.30)$ & 0.13 & $1.40(0.30-6.51)$ & 0.67 & $1.52(0.25-9.40)$ & 0.65 \\
\hline Long distance truck drivers & $2.03(0.89-4.63)$ & 0.09 & $1.57(0.65-3.77)$ & 0.31 & $1.08(0.35-3.33)$ & 0.89 & $5.96(1.05-33.80)$ & 0.04 \\
\hline Intercity bus drivers & $4.14(1.98-8.69)$ & 0.00 & $4.06(1.73-9.53)$ & 0.00 & $2.59(0.71-9.45)$ & 0.15 & & \\
\hline Pastoralists & $0.44(0.11-1.81)$ & 0.25 & $0.52(0.14-1.85)$ & 0.31 & & & & \\
\hline Road construction workers & $2.11(1.16-3.85)$ & 0.02 & $1.84(0.96-3.56)$ & 0.08 & $0.73(0.26-2.02)$ & 0.54 & $2.45(0.69-8.67)$ & 0.16 \\
\hline Female sex workers & $3.11(1.19-8.14)$ & 0.02 & $5.21(1.89-14.33)$ & 0.00 & $4.56(1.40-14.84)$ & 0.01 & $5.98(1.15-31.05)$ & 0.03 \\
\hline Police force & $1.07(0.52-2.20)$ & 0.86 & $1.26(0.56-2.85)$ & 0.58 & $0.80(0.23-2.80)$ & 0.73 & & \\
\hline Defense forces & $2.14(1.12-4.10)$ & 0.02 & $1.98(0.97-4.03)$ & 0.06 & $2.28(0.87-5.97)$ & 0.09 & $11.91(3.56-39.85)$ & 0.00 \\
\hline Factory workers & $0.51(0.17-1.50)$ & 0.22 & $0.55(0.18-1.66)$ & 0.29 & $0.30(0.06-1.45$ & 0.14 & $0.22(0.04-1.15)$ & 0.07 \\
\hline
\end{tabular}

$\mathrm{AOR}=$ adjusted odds ratio for sex, education and age.

Referent group=population of ANC catchment areas. 


\section{Discussion}

The analysis and interpretation of the findings by risk population groups provided a better understanding of the situations of the groups as they were major HIV intervention populations by the federal government of Ethiopia.

Generally, knowledge of preventive methods was fairly high. However, considerable gaps were observed among the rural, females, the age groups of 35 years and above and the illiterate segments of the population. Ethiopian DHS conducted in 2005 revealed that knowledge of preventive methods for limiting sex to one uninfected partner and use of condoms was $65.5 \%$ for urban and $28.0 \%$ for rural women, and; $75.5 \%$ for urban and $53.3 \%$ for rural men (5). In Jima town and its surroundings nearly two-thirds of the respondents had adequate knowledge score (13). Although the figures were not the same because of the difference in the nature of the studies, the pattern was similar, i.e., women and groups with less access to information were less knowledgeable on the preventive methods. From the findings it was easier to understand that knowledge of preventive methods was more than two-thirds amongst the groups that maybe driving the HIV epidemic in Ethiopia are long distance drivers, female sex workers, and uniformed services that expressed established sexual networks. Groups such as construction workers were also having comparable knowledge which may be due to policy influences as a result of mainstreaming and labor laws that demand HIV intervention activities in all development sectors in Ethiopia $(14,15)$.

It was revealed that knowledge of preventive methods was significantly higher in groups that had better access to information and interventions. However, it was lower in pastoralists who had limited access to modern media such as printed matters, radio and television. This underscores the need to design alternative strategies to improve access to correct the information to communities such as the pastoralists who are largely mobile in search of water and grazing land for their livestock. The programmers should also implement innovative strategies to address the needs of the non-literate and women.

Our study revealed that knowledge of preventive methods was lower in the age groups of 35 years and above compared to the younger age groups 15-24 years. From the different studies conducted on adolescents and youth, knowledge was considered as adequate in terms of knowing the three programmatically important preventive methods. However, it was also reported that there existed considerable levels of misconceptions about the transmission of HIV and prevention methods that led to the low level of comprehensive knowledge (16). Other segments of the population such as people in the informal business sector in Addis Ababa showed considerable misconceptions (17). In northwest Ethiopia, it was reported that although knowledge on HIV was reasonably high, considerable misconceptions were noted among the study population (18).

Magnitude of misconceptions showed higher levels almost in all groups but very high in groups that did not reveal higher levels of knowledge of preventive methods. However, it was surprising to see high levels of misconceptions among female sex workers as their knowledge of preventive methods was relatively high. Female sex workers and long distance drivers were the first groups put under biological as well as behavioural surveillance in Ethiopia $(19,20)$. Furthermore, the proportion of female sex workers that had comprehensive knowledge was very low. This was attributed to the presence of widespread misconceptions and incorrect information $(11,12)$.

A review of sexual behaviour among adolescents of South Africa revealed that this group did not have adequate knowledge of the transmission of HIV that translated into change in behaviours (21). In Mexico, a large scale study revealed that a high proportion of young people had intermediate level of HIV knowledge score $(46 \%),(22)$. In the same study, young men were more knowledgeable than young women. In another study, although the data were old, some misconceptions were observed among high school adolescents of New York City although there exists considerable messages and information about HIV/AIDS (23). In the Turkish population, significant misconceptions were reported among 11-83 years old in spite of the favourable knowledge and attitude (24). Among secondary school students in Nigeria and Iran, defective knowledge about transmission, causes and prevention was observed (25, 26). In Malaysia the level of knowledge on HIV was considered as being fairly good among the indigenous population (30\% to $50 \%)(27)$. Other studies in Malaysia had indicated high levels of knowledge among adolescents (28).

Condom use in every penetrative sexual act has remained one of the major indicators of behavior change in HIV/AIDS preventions. In this study, condom use was measured using two indicators, report of condom use during the last sexual encounter with non-regular sexual partners or paying sexual partner and pattern of condom use in any of the sexual relationships in the last 12 months (does not include condom use in married couples), which was described as consistent condom use.

The findings on female sex workers in terms of reporting condom use during last sexual encounter with paying partner and consistent condom use with non-regular sexual partner was consistently positive. This might indicate changes in behavior among high-risk groups such as female sex workers. Consistent condom use and condom use during last sexual encounter with paying sexual partners did not show statistically significant difference in all the groups except female sex workers. 
This might mean that condom use with high-risk partners such as female sex workers was similar across all groups. In a randomized controlled trial in high-risk settings in Nicaragua, it was demonstrated that condom use was significantly higher in paid sex than noncommercial sex (31). Higher proportion of female sex workers reported consistent condom use with paying clients $(77 \%)$ in Assossa (32). However these studies were at least three to four years old compared to the findings of our study. On the other hand, other studies have shown that consistent condom use was low among brothel-based female sex workers in India and Ethiopia (33-35).

Although there were not many studies that were inclusive of all the target groups that we studied, many researchers have produced study findings particularly on adolescents and youth and some on female sex workers and long distance truck drivers. Among 343 drivers in Bangladesh, less than a third (31\%) had ever used a condom, which was very low (36). Among female sex workers, the practice of condom use varied by type of partners with a tendency of low use utilization with partners of long-term companionship compared to casual partners. This was also reported by earlier studies (37). Others have indicated that condom use with casual partners was determined by the interaction between partners and less by attitudes and beliefs (unlike with established partners) (38). The negotiations, whether to request a partner to use or not to use condoms, relied on several factors including the type of partner, access, a priori knowledge and the fact that risk is perceived to the extent of influencing one's own decision. Long term sexual relationships tend to build some kind of norms and understanding between partners. In behavioral surveillance surveys, one of the major reasons for not using condoms was trusting a partner (11), which was often the case in other studies in Ethiopia.

\section{Conclusions}

The results of this study have shown encouraging in pointing out/to programmatic gaps. The study demonstrated the presence of considerable gaps in the level of knowledge as well as in obtaining correct information on HIV/AIDS among all target groups. Gaps were higher among pastoralists than population at ANC catchment area, women than men, older than younger age group. The dynamics of HIV/AIDS in hard-to-reach populations is not well studied and hence requires more attentions. Limited access to information compounded by barriers to getting correct information may contribute to sustaining HIV risk among women. The need for developing special approaches to provide correct information to women and the underprivileged is essential. We recommend use of strategic communication targeting different segments of the population and providing of accurate and comprehensive information.

Condom use was generally higher among the study groups that were prioritized by the HIV prevention programs such as female sex workers and the defense forces. However, considerable proportions of the study groups were not using condoms with non regular sex partners. Intensifying the HIV/AIDS prevention activities among the target groups expected to drive the epidemic and spread is important.

This may also indicate the presence of unrecognized drivers of the HIV epidemic and extended distribution of most at risk populations of the same such as female sex workers in emerging towns which are not covered by the study. We emphasis the need for understanding and addressing the root causes of the gaps in knowledge and self protection.

\section{Acknowledgements}

We acknowledge the institutions that implemented the behavioral surveillance survey: Federal Ministry of Health, Federal HAPCO, the Department of Community Health, Addis Ababa University, the Central Statistics Authority and the Ethiopian Public Health Association and the Global Fund for financing the survey.

Our heartfelt thanks go to the survey team: Drs Fikre Enquosellasie, Retta Ayele, Wuleta Lemma, Firehiwot Berhane, Tsigereda Gadissa and Asegid Woldu; and Mr. Mekonnen Tesfaye and Mr. Biratu Yigezu. Lastly, we recognize the contributions of many that participated in the survey including the people.

\section{References}

1. Tsega E, Mengesha B, Nordenfelt E, Hansson BG, Lindberg JL. Serological survey of human immunodeficiency virus infection in Ethiopia. Ethiop Med J 1988;26:179-84.

2. Lester FT, Ayehunie S, Zewdie D. Acquired immunodeficiency syndrome: seven cases in an Addis Ababa Hospital. Ethiop Med J 1988;26:13945.

3. Joint United Nations Program on HIV/AIDS (UNAIDS) and World Health Organization (WHO). AIDS epidemic update. UNAIDS: December 2007.

4. Federal Ministry of Health (FMoH), AIDS in Ethiopia. 6th Report, FMoH; September 2006.

5. ORC/Macro/CSA. Ethiopia Demographic and Health Survey 2005, ORC Macro, Calverton, Maryland, USA; 2006.

6. Hldadik W, Ismail S, Ahmed J, Woldu A, Messele T, Wuhib T. HIV/AIDS in Ethiopia: Where is the epidemic heading? Sex Transm Infect 2006;82(suppl 1): i32 - i35.

7. Mehret M, Khodakevich L, Zewdie D, Shanko B. Progression of Human Immunodeficiency Virus Epidemic in Ethiopia. Ethiop $J$ Health Dev. 1990;4:183--190.

8. Kefene H, Zewdie D, Desta B, Mehari H, Fekede H, Tadesse M, Ketema F, Kebede T. The Prevalence of HIV-1 antibodies in 106 tuberculosis patients. Ethiop J Health Dev 1990;4:197 - 200. 
9. Khodakevich L, Mehret M, Negassa H, Shanko B. Projections on the development of HIV/AIDS epidemics in Ethiopia. Ethiop $J$ Health Dev 1990;4:191-195.

10. Family Health International (FHI) and Implementing AIDS Prevention and Care Project (Impact). Behavioral Surveillance Surveys. Guidelines for repeated behavioral surveillance surveys in populations at risk of HIV. 2000.

11. Mitike G, Lemma. W, Berhane F, HIV/AIDS Behavioral Surveillance Survey, Round One. Federal Ministry of Health: Ethiopia; 2002.

12. Mitike Mekonnen $\mathrm{T}$, Ayele R, Gadisa $\mathrm{T}$, Enqusillasie F, Lemma W, Berhane F, Yigezu B, Woldu A. HIV/AIDS Behavioral Surveillance Survey (BSS), Round Two. Federal Ministry of Health: Ethiopia; 2005.

13. Belachew T, Jirra C. Mamo Y. Knowledge, attitude and practice about HIV/AIDS and Voluntary counseling and testing among the urban communities in Jimma town and its rural surrounding, Southwest Ethiopia. Ethiop J Health Sci 2004; 14:27-40.

14. HIV/AIDS Prevention and Control Office, Mainstreaming Guideline on HIV/AIDS interventions in Federal Ministries and Organizations, Ethiopia. HAPCO; August 2003.

15. $\mathrm{MOH}$. Strategic Framework for the National Response to HIV/AIDS in Ethiopia for 2000-2004. Ministry of Health: Addis Ababa; Sept. 1999.

16. Haile M:. 2005, Assessments of HIV/AIDS related knowledge among window of hope population in kombolcha town, South Wello Zone, Amhara Regional State. MPH thesis: Department of Community Health, Addis Ababa University; 2005.

17. Abera Z. Knowledge, Attitude and behavior (KAB) on HIV/AIDS/STDs among workers in the informal sector in Addis Ababa. Ethiop $J$ Health Dev 2003; 17:53 - 61 .

18. Alemu S, Abseno N, Degu G, Wondimkun $Y$, Amsalu S. Knowledge and attitude towards voluntary counseling and testing for HIV: A community-based study in northwest Ethiopia. Ethiop J Health Dev 2004;18:82 - 89.

19. Mehret M, Khodakevich L, Zewdie D, Ayehunie S, Shanko B, Gizaw G, Demissew B, Kebede T, Yadetta M, Ketema F, Fessehaye T, Tadesse M, Manore H, Hailu E, Adal G, Lakew S. HIV-1 infection and some related factors among female sex workers in Addis Ababa. Ethiop $J$ Health Dev 1990;4:171-378.

20. Negassa H, Khodakevich L, Kefenie H, Zewdie D, Shanko B. Surveillance of AIDS cases in Ethiopia. Ethiop J Health Dev 1990;4:107-113.

21. Hartell CG. HIV/AIDS in South Africa: A review of sexual behavior among adolescents. Adolescence 2005;40: 171-181.

22. Tapia-Aguirre A., Arillo-Santilan E., Allen B., Angeles Llerenas A., Cruz-Valdez A., LazcanoPonce E. Associations among condom use, sexual behavior and knowledge about HIV/AIDS: A study of 13, 293 public school students. Archives of Medical Research 2004;35:334 - 343.

23. Sikand A, Fisher M, Friedman SB. AIDS Knowledge, Concerns and behavioral changes among inner-city high school students. Journal of Adolescent Health 1996;18:325-328.

24. Ayrani U. AIDS knowledge and attitudes in a Turkish population: an epidemiological study. $B M C$ Public Health 2005;5:95.

25. Nwokocha AC, Nwakoby BN. Knowledge and Attitude and Behavior of secondary (high) school students concerning HIV/AIDS in Enugu, Nigeria in the year 2000. J Pediatr Adolescent Gynecol 2002;15:93-96.

26. Tavoosi A, Zaferani A, Enzevaei A, Tajik P, Ahmadinezhad Z. Knowledge and attitude towards HIV/AIDS among Iranian students. BMC Public Health 2004;4:17.

27. Anita S, Zahir WM, Saiah A, Rahimah MA, Shaari BN. HIV/AIDS knowledge, attitude and risk behaviors among Orang Asli in Peninsular Malaysia. Med J Malaysia 2007;62:227 -33.

28. Zulkifli SN, Wong YL. Knowledge, attitude and beliefs related to HIV/AIDS among adolescents in Malaysia. Med J Malaysia 2002;57:3-23.

29. Gordon G, Mwale V. Preventing HIV with Young People: A case study from Zambia. Reproductive Health Matters 2006;14:68 -79.

30. Lindberg CE. Knowledge, Self-efficacy, Coping and condom use among urban women. Journal of the Association of Nurses in AIDS care 2000;11(5):8090.

31. Egger M, Pauw J, Lopatatzidis A, Medrano D, Paccaud F, Smith GD. Promotion of condom use in high- risk setting in Nicaragua: a randomized controlled trial. Lancet 2000;355:2101 - 05 .

32. Eshetu M, Kebede D, Ismail S. Behavioral Survey for HIV/AIDS infection in Assosa among the general population and commercial sex workers. Ethiop J Health Dev 2004;18:75-81.

33. Dandona R, Dandona L, Gutierrez JP. High risk of HIV in non-brothel based sex workers in India. $B M C$ 2005; 5:87.

34. Alene GD. Knowledge and practice of condom in preventing HIV/AIDS infection among commercial sex workers in three small towns of northwestern Ethiopia. Ethiop J Health Dev 2002;16:277-286.

35. Negash Y, Gebre B, Benti D, Bejiga M. Community based study on knowledge, attitude and practice (KAP) on HIV/AIDS in Gambella town, Western Ethiopia. Ethiop J Health Dev 2003;17:205 - 213.

36. Gibney L, Saquib N, Metzger J. Behavioral Risk Factors for STD/HIV transmission in Bangladesh's trucking industry. Soc Sci Med 2003;56:1411-1424.

37. Outwater A, Nkya L, Lwihula G, O'Connor P, Leshabari M, Nguma J, et al. Patterns of partnership and condom use in two communities of female sex 
workers in Tanzania. Journal of the Association of Nurses in AIDS Care 2000;11:46-54.

38. De Vissser, Smith A. Relationship between sexual partners influences rates and correlates of condom use. AIDS Education and Prevention 2001;13:413427. 